\title{
Penyusunan Video Karakteristik Vegetasi Pantai Trisik sebagai Alternatif Sumber Belajar Sub-Materi Kekhasan Ekosistem Pesisir Pantai Pasir untuk Siswa SMA
}

\author{
Destri Ratna Ma'rifah, Sukirman, Agung W. Subiantoro \\ Progam Studi Pendidikan Biologi, Universitas Negeri Yogyakarta \\ Karangmalang, 55281 \\ surat elektronik: de s3@yahoo.co.id
}

\begin{abstract}
ABSTRAK
Penelitian ini bertujuan untuk mengetahui karakteristik vegetasi alamiah khas pesisir pantai pasir berdasarkan ciri morfologi dan jenis tumbuhan di pesisir Pantai Trisik, Kulon Progo, potensi serta kualitas video karakteristik vegetasi alamiah khas pesisir pantai pasir tersebut sebagai yang disusun sebagai alternatif sumber belajar biologi. Penelitian ini merupakan penelitian dan pengembangan dengan model 4D (define, design, develop, dan disseminate). Hasil penelitian menunjukkan tumbuhan penciri ekosistem pesisir di Pantai Trisik, yaitu Canavalia maritima, Spinifex littoreus, Ipomoea pes-caprae, Pandanus tectorius, dan Casuarina equisetifolia. Berdasarkan aspek kesesuaian dengan standar isi KTSP SMA, dinilai baik oleh semua reviewer. Berdasarkan aspek kualitas instruksional, dinilai baik oleh peer-reviewer dan dosen ahli materi; dinilai sangat baik oleh dosen ahli media dan guru. Berdasarkan aspek kualitas teknis, dinilai baik oleh dosen ahli materi; dinilai sangat baik oleh peer-reviewer, dosen ahli media, dan guru.
\end{abstract}

Kata kunci: Karakteristik, Vegetasi, Video, Ekosistem Pantai Pasir, Pantai Trisik

\section{Pendahuluan}

Ekosistem pesisir merupakan salah satu contoh dari beragamnya ekosistem di Indonesia. Pantai Trisik merupakan salah satu contoh dari keanekaragaman ekosistem pesisir. Salah satu komponen biotik penciri ekosistem adalah komunitas tumbuhan di ekosistem yang bersangkutan. Mosaik komunitas tumbuhan dalam lanskap inilah yang dinamakan vegetasi (Kartawinata, 20I0). Vegetasi yang ditemukan di Pantai Trisik antara lain Spinifex, Ipomoea pes-caprae, kaktus, pandan berduri, cemara laut, akasia, bakau, waru laut dan beberapa jenis rerumputan. Vegetasi tersebut memiliki ciri yang hampir sama dengan pesisir pantai lain di Yogyakarta. Namun demikian, terdapat tumbuhan yang tidak ditemukan di pesisir pantai lain di Yogyakarta, yaitu Canavalia maritima.

Kekhasan vegetasi di ekosistem pesisir pantai dapat digunakan sebagai sumber belajar dalam memahami materi ekosistem pesisir pantai sesuai dengan standar kompetensi dan kompetensi dasar KTSP SMA. Materi ini dapat digunakan untuk mencapai standar kompetensi memahami manfaat keanekaragaman hayati dan kompetensi dasar mendeskripsikan konsep keanekaragaman gen, jenis, dan ekosistem melalui kegiatan pengamatan.

Guna menghadirkan fenomena kekhasan vegetasi di ekosistem pesisir pantai ke hadapan siswa, diperlukan suatu media. Media akan menjadi baik apabila dapat membawa kondisi yang nyata bukan sekadar simbolsimbol, sehingga siswa memperoleh visualisasi objek dan gejala biologi serta seakan-akan mengalami kegiatan studi lapangan. Media juga diharapkan mampu memfokuskan pada hal yang ingin dipelajari sehingga siswa lebih mudah memahami. Media yang dianggap sesuai adalah video karena mampu mengabadikan fenomena yang berupa proses, sehingga dapat diputar ulang bila diperlukan tanpa terbatas waktu, serta dapat menyajikan visualisasi kenyataan dari fenomena yang belum tentu dapat ditemui saat studi lapangan baik berupa gambar maupun gerak.

Berdasarkan hasil wawancara kepada guru pembimbing Praktik Pengalaman Lapangan di SMA N I Prambanan, Klaten, hingga sekarang belum ada bahan ajar bentuk cetak maupun multimedia (video, film dokumenter) yang dapat digunakan guru dalam menyampaikan materi tentang vegetasi yang menjadi salah satu ciri dari ekosistem pesisir. Oleh karena itu, penelitian ini dimaksudkan untuk membuat video yang 
dapat digunakan dalam praksis pembelajaran sebagai sumber belajar.

Sumber belajar biologi adalah segala sesuatu, baik benda maupun gejalanya, yang dapat dipergunakan untuk memperoleh pengalaman dalam rangka pemecahan permasalahan biologi tertentu. Sumber belajar memungkinkan dan memudahkan terjadinya proses belajar. Sumber belajar biologi dalam proses pembelajaran biologi dapat diperoleh di sekolah atau di luar sekolah (Colin Marsh dalam Suhardi, 2007).

Pantai Trisik adalah salah satu pantai yang terdapat di wilayah Kecamatan Galur, Kulon Progo, Yogyakarta (Pramono, 2010). Pantai ini memanjang sekitar I,5 sampai $2 \mathrm{~km}$ ke arah timur dan barat. Pantai yang curam mengakibatkan tumbuhan pesisir dapat ditemui setelah jaun dari garis pantai ke arah daratan. Mendekati daratan pesisir yang landai mulai ditumbuhi tumbuhan pesisir yang menjalar dan tumbuhan berkayu. Substrat dasar di pantai ini adalah pasir sehingga termasuk tipe pantai pasir. Pasir yang terdapat di pantai ini merupakan pasir besi yang berawrna kehitaman sehingga mudah panas bila terpapar matahari.

Tiap-tiap lingkungan memiliki karakteristik tersendiri yang menyebabkannya dapat ditumbuhi oleh tumbuhan (Cox \& Moore, I985). Di antara pengaruh yang mencolok pada pesisir adalah angin kencang dengan hembusan garam, kadar garam tinggi dalam tanah, sesekali tergenang oleh air laut, penyaliran cepat, dan kelasakan pasir yang bebas. Mengingat berbagai faktor ini, tumbuhan yang hidup pada pantai berpasir secara tegas dapat dikatakan tumbuh dalam lingkungan kering yang tak jauh berbeda dengan keadaan gurun. Di antara spesies yang tersesuaikan pada kehidupan di pasir adalah Sesuvium portulacastrum yang berdaun kecil dan tebal; Sporobolus virginicus dan Remirea maritima yang berdaun keras dan berduri; lavender laut (Tournefartia) yang daunnya berbulu; spesies Ipomoea yang berdaun lir-kulit; dan Canavalia obtusifolia serta Ipomoea biloba yang berakar dalam untuk menyadap air dari tanah yang berada di bawah lapisan pasir. Di beberapa daerah tropika, kegiatan ombak dengan mudah sekali dapat menggerakkan pasir, sehingga lapis-alas yang dibentuknya bagi tumbuhan tak-mantap. Tumbuhan Ipomoea biloba, I. pescaprae, Canavalia obtusifolia, dan C. rosea membantu menahan gumuk pasir yang dibentuk oleh angin (Ewusie, 1990).

Menurut Webb \& Tracey (dalam Kartawinata, 2010), vegetasi alami bukan hanya merupakan sebuah komponen dari keanekaragaman hayati yang menyediakan sumber daya alam, tetapi juga mempunyai peran penting dalam berbagai proses alam yang menunjang kehidupan manusia, seperti hidrologi dan iklim. Dalam suatu vegetasi yang terlibat hanyalah tumbuhan. Jika komponen fisik dan komponen biotik lain diintegrasikan ke dalam suatu vegetasi, maka akan terbentuk suatu ekosistem.

Faktor biotik dipengaruhi oleh faktor abiotik lingkungan. Suhu dapat mempercepat hilangnya air dari tumbuhan dan cenderung mengeringkannya. Kelembaban udara mendorong pertumbuhan, dan membatasi hilangnya air bagi pertumbuhan. Angin mempercepat hilangnya air dan cenderung mengeringkannya, membantu tepung sari (dalam proses penyerbukan), mendorong penyebaran penyakit. Sinar matahari mendorong terjadinya penguapan (Kartasapoetra, 2006).

\section{Metode Penelitian}

Penelitian ini merupakan penelitian dan pengembangan yang dilakukan untuk membuat sumber belajar berbentuk video. Model yang digunakan dalam penelitian ini adalah model 4D (define, design, develop, disseminate).

Tahap penetapan meliputi penetapan karakteristik morfologis tumbuhan pesisir pantai berpasir, standar kompetensi dan kompetensi dasar dalam KTSP SMA.

Tahap perencanaan meliputi kegiatan berikut.

a. Mengadakan penelitian untuk mengetahui karakteristik tumbuhan penyusun vegetasi di pesisir Pantai Trisik dengan teknik pengumpulan data belttransect method.

b. Penyusunan story board sesuai dengan tujuan yang ingin dicapai.

c. Pemilihan foto dan video disesuaikan dengan kriteria teknis dan kurikulum. Kriteria teknis berhubungan kualitas foto maupun video, sehingga foto maupun video dapat diamati dengan baik dan jelas. Kriteria kurikulum berhubungan dengan seleksi foto maupun video yang dapat mewakili keberagaman dan karakteristik morfologis tumbuhan di pesisir Pantai Trisik.

d. Program yang digunakan untuk membuat video adalah Ulead Video Studio version II, Video Cutter Max, Any Video Converter, Adobe Premiere CS4, dan CamStudio 2.6b.

e. Pembuatan prototipe produk awal.

Tahap pengembangan meliputi kegiatan penilaian dan revisi video. Video direview oleh beberapa reviewer, antara lain peer-reviwer, dosen ahli materi dan media dan guru. Video ditanggapi oleh siswa pada aspek pemahaman dan ketertarikan mereka. Video yang selesai direvisi disebarluaskan pada tahap disseminate.

Tahap disseminate dilakukan dengan membuat kopian dari video untuk diserahkan kepada guru SMA, dosen pembimbing dan mengunggah pada akun dengan alamat http://destriratna.blogspot.com agar dapat diunduh secara luas oleh pendidik maupun pelajar.

Instrumen yang digunakan adalah:

I. Lembar penilaian berupa angket berbentuk check list dan saran dari reviewer tentang sumber belajar dilihat dari aspek kesesuaian dengan Standar Isi dalam KTSP, kualitas instruksional, dan kualitas teknis. 
2. Lembar tanggapan berupa angket berbentuk check list dari siswa dilihat dari aspek pemahaman dan teknis (ketertarikan) terhadap video.

Lembar penilaian yang digunakan dalam penelitian ini menggunakan empat alternatif pilihan. Angket tanggapan reviewer memiliki empat alternatif pilihan, yaitu Sangat Baik (SB), Baik (B), Kurang (K), Sangat Kurang (SK). Angket tanggapan siswa memiliki empat alternatif pilihan, yaitu Sangat Setuju (SS), Setuju (S), Kurang Setuju (KS), dan Tidak Setuju (TS). Instrumen yang digunakan akan divalidasi oleh kedua dosen pembimbing yang juga merupakan dosen ahli media dan dosen ahli materi.

Data yang diperoleh merupakan data kualitatif berupa hasil penilaian dan saran/ masukan dari reviewer. Data penilaian reviewer dianalisis persentase kategori nilai tiap indikator. Data persentase kategori nilai tiap indikator dianalisis persentase kategori nilai untuk tiap aspek penilaian. Data hasil tanggapan siswa dianalisis persentase kategori nilai dari masing-masing aspek. Data yang berupa saran/masukan dari reviewer dirangkum dan diseleksi relevansinya. Saran yang dianggap relevan digunakan sebagai bahan revisi terhadap video dan sebagai masukan dalam penggunaan video di masa yang akan datang.

\section{Hasil dan Pembahasan}

Penelitian ini diawali dari potensi yang terdapat di pesisir Pantai Trisik. Potensi yang dimaksud adalah beranekaragamnya vegetasi khas pesisir pantai berpasir, sehingga dapat dikembangkan menjadi sebuah sumber belajar alternatif berbentuk video.

Tumbuhan yang terdapat di pesisir Pantai Trisik antara lain Fimbristylis cymosa, Chloris barbata, Canavalia maritima, Cyperus rotundus, Bulbostylis capilaris, Tridax procumbens, Opuntia cochenillifera, Crotalaria sp, Pandanus tectorius, Vernonia cinerea, Zoysia matrella, Fimbristylis annua, Hedyotis corymbosa, Wedelia sp, Sida thombifolia, Dactyloctenium aegypticum, Emilia sonchifolia, Hyptis sp, Eleusine indica, Stacytarphata jamaicensis, Leucas lavandulifolia, Casuarina equisetifolia, Ipomoea pescaprae, Spinifex littoreus, Eragrotis amabilis, Cyperus difformis, dan Euphorbia atoto.

Hasil pengukuran terhadap faktor abiotik sebagai berikut. Suhu tanah dari ketiga stasiun menunjukkan kisaran antara $26^{\circ} \mathrm{C}$ hingga $43^{\circ} \mathrm{C}$. Kelembaban udara di lokasi pengamatan berkisar antara $46 \%$ sampai $87,7 \%$. Kecepatan angin berkisar antara $0,7 \mathrm{~m} / \mathrm{s}$ hingga 7,4 $\mathrm{m} / \mathrm{s}$. Intensitas cahaya di lokasi pengamatan berkisar antara 4 x I00 lux hingga 1375 x 100 lux. Suhu udara berkisar antara $26^{\circ} \mathrm{C}$ hingga $46^{\circ} \mathrm{C}$. Kelembaban tanah berkisar antara $0 \%$ hingga $100 \%$ di seluruh lokasi pengamatan.

Berdasarkan pengkajian terhadap syarat sumber belajar oleh Djohar (dalam Alfian, 2010), vegetasi di pesisir Pantai Trisik dapat digunakan sebagai sumber belajar alternatif. Hal-hal yang dikaji antara lain:

a. Kejelasan potensi ketersediaan objek dan permasalahan yang diangkat

b. Kesesuaian dengan tujuan pembelajaran

c. Kejelasan sasaran materi dan peruntukannya

d. Kejelasan informasi yang diungkap

e. Kejelasan pedoman eksplorasi

f. Kejelasan perolehan yang diharapkan

Pada tahap design diperoleh data vegetasi, storyboard dan prototipe video. Data vegetasi berupa daftar inventaris, foto, dan video. Prototipe video akan dikembangkan berdasarkan hasil penilaian dan saran dari reviewer pada tahap develop.

Pada tahap develop diperoleh data hasil penilaian reviewer dan siswa terhadap video. Hasil penilaian peerreviewer menunjukkan bahwa pada aspek kesesuaian dengan KTSP SMA, video yang dibuat termasuk ke dalam kategori baik (dengan persentase 51,7\%). Hasil penilaian dari dosen ahli materi menunjukkan bahwa pada aspek ini, video yang dibuat termasuk ke dalam kategori baik (dengan persentase sebesar 39\%). Hasil penilaian dari dosen ahli media menunjukkan bahwa pada aspek ini, video yang dibuat termasuk ke dalam kategori baik (dengan persentase sebesar 44,3\%). Hasil penilaian dari guru menunjukkan bahwa pada aspek ini, video yang dibuat termasuk ke dalam kategori baik (dengan persentase $72,1 \%$ ). Secara umum, reviewer menyatakan bahwa video yang dibuat memiliki kualitas yang baik untuk aspek kesesuaian dengan Standar Isi dalam KTSP.

Pada aspek kualitas instruksional, hasil penilaian dari peer-reviewer menunjukkan bahwa video yang dibuat termasuk ke dalam kategori baik (dengan persentase $49 \%$ ). Hasil penilaian dari dosen ahli materi menunjukkan bahwa video yang dibuat termasuk ke dalam kategori baik (dengan persentase 36,4\%). Hasil penilaian dari dosen ahli media menunjukkan bahwa video yang dibuat termasuk ke dalam kategori sangat baik (dengan persentase 36\%). Hasil penilaian dari guru menunjukkan bahwa video yang dibuat termasuk ke dalam kategori sangat baik (dengan persentase 53,4\%).

Pada aspek kualitas teknis, hasil penilaian dari peerreviewer pada aspek teknis menunjukkan bahwa video yang dibuat termasuk ke dalam kategori sangat baik (dengan persentase 52,2\%). Hasil penilaian dari dosen ahli materi menunjukkan bahwa video yang dibuat termasuk ke dalam kategori baik (dengan persentase 5I,9\%). Hasil penilaian dari dosen ahli media menunjukkan bahwa video yang dibuat termasuk ke dalam kategori sangat baik (dengan persentase 48\%). Hasil penilaian dari guru menunjukkan bahwa video yang dibuat termasuk ke dalam kategori sangat baik (dengan persentase 59,2\%).

Berdasarkan rerata tanggapan siswa terhadap semua kriteria, diperoleh hasil sebanyak $52,9 \%$ siswa 
menyatakan setuju terhadap penggunaan video Keanekaragaman Vegetasi Pesisir Trisik, Kulon Progo.

Pada tahap disseminate dihasilkan kopian dari video dalam CD/DVD dan video yang dapat diunduh dari akun dengan alamat http://destriratna.blogspot.com.

Penelitian ini berawal dari potensi yang terdapat di pesisir Pantai Trisik, Kulon Progo. Potensi tersebut berupa beranekaragam jenis dan karakteristik tumbuhan di pesisir Pantai Trisik yang mampu mencirikan ekosistem pesisir pantai berpasir. Hasil dari pengamatan terhadap potensi tersebut akan digunakan sebagai bahan pembuatan alternatif sumber belajar berupa video. Video ini diharapkan dapat digunakan oleh guru untuk memberikan visualisasi nyata kepada siswa tentang objek dan gejala biologi yang sulit diamati saat pembelajaran di kelas.

Pada tahap penetapan (define) ditetapkan dalam tahap ini, antara lain karakteristik vegetasi pesisir pantai berpasir, Standar Kompetensi dan Kompetensi Dasar dalam KTSP SMA, bentuk alternatif sumber belajar yang akan dibuat, dan tujuan pembuatan alternatif sumber belajar. Tahap perancangan (design) dimulai dari persiapan guna memperoleh bahan dalam pembuatan video hingga dihasilkan prototipe video. Pada tahap pengembangan (develop), prototipe video dimintakan review kepada dosen ahli dan guru di sekolah guna melihat kualitas video berdasarkan aspek yang telah ditetapkan. Setelah mendapatkan review, video akan direvisi sesuai masukan dari dosen ahli dan guru. Video yang telah direvisi, dimintakan tanggapan dari siswa di sekolah. Hasil tanggapan siswa dijadikan masukan guna revisi selanjutnya. Aspek yang dinilai antara lain kesesuaian dengan standar isi dalam KTSP, kualitas instruksional, dan kualitas teknis.

Review yang diberikan oleh mahasiswa, dosen maupun guru tidak hanya berupa nilai tetapi juga berupa saran. Berdasarkan saran yang diperoleh dari reviewer, dilakukan revisi terhadap video. Tidak semua saran dijadikan sebagai bahan untuk revisi, tetapi hanya saran yang dianggap relevan.

Berdasarkan penilaian kualitas Keanekaragaman Vegetasi Pesisir Trisik, Kulon Progo, hampir seluruhnya menunjukkan kategori baik hingga sangat baik. Selain itu, hasil tanggapan siswa terhadap video menunjukkan bahwa lebih dari separuh siswa menyatakan setuju dalam tiap kategori sehingga dapat dikatakan video ini cenderung dapat diterima oleh siswa untuk dijadikan sebagai alternatif sumber belajar untuk materi keanekaragaman hayati. Oleh karena itu, video ini dapat dikatakan layak untuk dipergunakan dalam proses pembelajaran.

\section{Simpulan}

Berdasarkan hasil penelitian dan pembahasan mengenai Penyusunan Video Karakateristik Vegetasi Pantai Trisik sebagai Alternatif Sumber Belajar Sub- materi Kekhasan Ekosistem Pesisir Pantai Pasir untuk Siswa SMA, dapat disimpulkan beberapa hal sebagai berikut.

I. Karakteristik vegetasi alamiah khas pesisir Pantai Trisik yaitu beraneka ragam tumbuhan alamiah khas penanda ekosistem pesisir pantai pasir dengan ciri morfologi antara lain daun sering berlapis lilin, daun tebal, daun sempit, batang berlapis lilin, akar memanjang di bawah permukaan tanah, dan diantaranya Ipomoes pes-caprae, Canavalia maritima, Spinifex littoreus, Pandanus tectorius; dengan kondisi faktor abiotik yang merata di pesisir Pantai Trisik.

2. Video Karakteristik Vegetasi Alamiah Khas Pesisir Pantai Trisik berpotensi sebagai sumber belajar alternatif untuk materi keanekaragaman hayati, sub materi keanekaragaman ekosistem.

3. Berdasarkan penilaian oleh peer-reviewer, dosen ahli media, dosen ahli materi, dan guru, Video Karakteristik Vegetasi Alamiah Khas Pesisir Trisik memperoleh nilai dengan kategori baik sampai dengan sangat baik.

\section{Daftar Pustaka}

Alfian, Fanny. (2010). Penyusunan Media Pembelajaran Animasi Hewan Transgenik dan Tanaman Transgenik Menggunakan Program Macromedia Flash Pro 8. Skripsi tidak diterbitkan. Program Sarjana Pendidikan Biologi FMIPA UNY.

Cox, C. B. \& Moore, P. D. (1985). Biogeography An Ecological and Evolutionary Approach Fourth Edition. London: Blackwell Scientific Publications.

Kartawinata, Kuswata \& Danimiharja, Sarkat. (1992). Ekologi dan Biologi Tropika. (Ian Deshmukh Terjemahan). Jakarta: Yayasan Obor Indonesia.

Pramono, Agung T. (2010). Pantai Trisik. Diakses dari http://www.jogjatrip.com/id/4I2/pantai-trisik pada Kamis, 30 Desember 2010 pukul I9.30 WIB.

Suhardi. (2007). Pengembangan Sumber Belajar Biologi. Yogyakarta: Jurusan Pendidikan Biologi FMIPA UNY.

Tanuwidjaja, Usman. (1990). Pengantar: Ekologi Tropika (Ewusie, J.Y. Terjemahan). Bandung: Penerbit ITB. 